\title{
The Sociological Semantics of Complex Systems
}

\author{
Prof. Andrea Pitasi (Corresponding Author) \\ Dept. of Business Administration and Management, G. D’Annunzio University \\ Viale Pindaro 42, 65100 Pescara, Italy \\ E-mail: profpitasi@gmail.com
}

Doi:10.5296/jsr.v5i1.5953ＵRL: http://dx.doi.org/10.5296/jsr.v5i1.5953

\begin{abstract}
The concept of complex systems is one of the most common and abused by sociological semantics. Both complexity and system are epistemological terms which contribute to reshape the scientific research design and conceptual frames. Nevertheless, complexity and system are often used by everyday life in several misleading ways: for example complex is often meant by common sense as a synonym for difficult, complicate, hard to understand, obscure and system is used by common sense as a synonym of "way " or mechanism and is often geographically rooted (the Italian political system, for instance). Common sense generates misleading uses and affects public opinion about the understanding of science. This paper is not focused on the history and evolution of the concept of complex system it rather is aimed at reconstructing this concept in the current sociological depistemology to let complex systems fully express their revolutionary and reconfigurational powers for social and political science research
\end{abstract}

Keywords: Complexity, System, Variety, Density, Epistemology

\section{Introduction}

This essay is theoretical and provides a contribution to sociological epistemology by introducing a conceptual and semantic reconstruction of complex systems. Complex systems conceptually crash with the world taken for granted (Berger-Luckmann 1966, Berger-Berger-Kellner, 1973). To understand complex systems it is strategic to re-set a question Niklas Luhmann inspired: "how can an order be created that transforms the impossible into the possible and the improbable into the probable?" (Luhmann, 1990 : 87).

Impossible and improbable are dramatically rejected by the world taken for granted of common sense that is why nothing relevant can derive from the so called "social reality" in its daily life shapes. Complex systems shape fluctuating and spiral-like orders (Imada, 2008: $21-23$; 98-104) and they construct and evolve those second level orders which are the stargate to turn impossible and improbable into possible and probable due to "the capacity of sociologists to affect change in the common sense of the publics they address" (Burawoy, 2014:151). The contribution of complex system (sociological) theory is pivotal for two deconstructive reasons at least. 1) to enlighten the oddities, gaps, discontinuities through the 
ages while non systemic sociology often tries to search for its key questions in the past creating the misleading illusion of a linear cause-effect link though the ages 2) to enlighten that empirical sociological research can be and often is misleading for a great evolution of sociology as a science. 2.1 Empirical sociology seems to ignore that data merely mirror the conceptual categories they derive from. It might seem a problem of deduction but inductive research has the same problem or rather induction is even more dramatic as in deduction conceptual categories are manifest while in induction they are latent. The problem that empirical data do not exist independently form conceptual formalized categories (in deduction) or by latent ideal value based categories (in induction) is evident in both qualitative and quantitative research. 2.2 Supposing the most accurate and methodologically transparent empirical research, most sociological findings are tendentially irrelevant for the evolution of complex systems. For example what public opinion and common sense define absurd after a survey(for example the idea man can fly before the Lindberghs'invention) simply states that public opinion find it absurd but it means nothing for the further systemic evolution (flying is now common sense). Viceversa, if a survey investigates what the majority of public opinion think, the fact that the majority thinks something does not mean that it is the most functional and viable trend for systemic evolution.

Spiral -like fluctuating systems operate though trajectories and trends common sense very seldom can imagine. For Instance, common sense interacts with familiarity where everything is taken for granted (including the most irrational beliefs in religion, for example) while key social change on a large scale mostly depends on algorithmic reconfigurations of the converging patterns among strange agents (Seabright, 2010). The more sociological theory evolves through wider and wider horizon (just like Beck's cosmopolitan vision, see Beck (2006) the more common sense sinks into a proletarian ,local and nationalistic view (Robyn, 2005) . Beck sharply describes the key features of the cosmopolitan vision as follows "As a counter-image to the territorial prison theory of identity, society and politics we can provisionally distinguish five interconnected constitutive principles of the cosmopolitan outlook:

First, the principle of experience of crisis in world society. The awareness of interdependence and the resulting civilizational community of fare induce by global risks and crises which overcomes the boundaries between internal and external, us and them, the national and the international; second, the principle of recognition of cosmopolitan differences and the resulting cosmopolitan conflict character and the (limited) curiosity concerning differences of culture and identity; third, the principle of cosmopolitan empathy and of perspective taking and the virtual interchangeability of situations (as both an opportunity and a threat); fourth the principle of the impossibility of living in a world society without borders and there consulting compulsion to redraw old boundaries and rebuild old walls; fifth the mélange principle, the principle that local, national, ethnic, religious and cosmopolitan cultures and traditions interpenetrate, interconnect and intermingle-cosmopolitanism without provincialism is empty, provincialism without cosmopolitism is blind". (Beck, 2006: 7). Global systemic trends are cosmopolitan, common sense is local. One more example that sociological trends and social trends live parallel lives is the natural /artificial coding. For common sense, emotions are nature, the parenthood need is nature while writing an essay is 
artificial, using a computer is artificial, IS-LM curve is artificial and so on. Sociological theory dramatically explained that human beings quit to be natural when they lightened their first fire on (Goudsblom, 1994).

\subsection{Theory}

Systemic sociology needs to be redesigned to manage the exceeding variety of emerging scenarios and high variety and high density complex evolutionary trends in which natural sciences and social ones converge in reframing the so called "natural reality". The natural reality is: something meaningless in se (since the first man ever switched a fire on and dressed. See Goudsblom, 1994) and systemically relevant merely as a thematic subject of positive and artificial self referential patterns .

This essay is about the place of sociology in the general science of complex systems from an interdisciplinary perspective starting from a social system (system/environment) paradigm to focus on psychic, systems, biosystems and social systems.

This essay subscribes the statement that "at the beginning of the twenty- first century we should consider the relevance of the physics of complexity for contemporary sociology/social sciences" (Urry, 2003: 120). Complexity, as a very basic definition can be considered the exceeding variety level which requires systemic selections to make sense. Variety must be also understood also expression of exceeding density which is even more hard to understand by common sense as it often confuses growth and development. Selecting variety contingently generates development, increasing and selecting density generates short term growth and mid-long term destruction as witnessed by the Malthus Trap, for instance (Pitasi 2011, 2012). The evolution of the concept of system though the $\mathrm{XX}$ century and the beginning of the XXIst one was featured by a rather sterile debate between the axiom that systems are mere epistemological criteria and the axiom that systems exist in nature, for real.

These two axioms shaped two different sty systemic visions which in the beginning of the XXIst century were dramatically reshaped by the increasing convergence among Nanotechnologies, Robotics, Informatics, Genetics and Neurosciences the so called Convergent technologies (CT).

The two axioms powerfully merged in an immaterial, global constellation of energy and information in which digitalization shapes meaning and the sense making process. Communication becomes the only procedural form of systemic self reproduction. As Luhmann brilliantly wrote: «for a theory of autopoietic systems, only communication is a serious candidate for the position of the elementary units of the basic self referential process of social systems». (Luhmann, 1990: 6).

Niklas Luhmann (1927-1998) died before digitalization replaced the idea that virtual and concrete items were separated entities: digitalization amazingly demonstrated everything and essentially science, technology and business first of all might be digitalized. Also the most concrete and physical items can be digitalized or rather are intrinsically digital. The paradigm shifts within the systemic approach summarized in the table below clearly show that P1 was featured by a very "physical reification of items such as nature, society, people and so on thus a very analogical, concrete narrowed minded approach to "reality".

Luhmann's contribution by introducing the system/environment code and then by the 
autopoietic turn were pivotal to describe the new scenarios of globalization in which dematerialization turns everything into communication flows which let circulate capitals in real time with no place bounds. Once again, Luhmann's writings anticipated the understanding of emergence in the globalized age. Nevertheless, Luhmann's vision was completed before digitalization entered the global scale. The increasing variety and the growing density, for example in demography, revealed that prescriptive, normative and value based social ideologie no longer work as each of them falls in the ontology trap by which each ideology consider itself right, real and sound and any other as a mere point of view. Values usually shape taken for granted worlds but a great sociologist able to start social change up would not work on values and subjective discourses inspired by politics or religion, s/he would focus on a container theory of society (Beck, 2000: 23) serving as an operational system expanding global platforms (Globus) to let circulate the enormous variety of memetic catalogues named Mundus (Pitasi-Mancini, 2012).

\section{Research design}

Starting from the key four paradigms of the systemic approach, this essay underlines that these paradigms do not describe a mere history of systemic thinking as they all four still belong to the systematics of science and not to its history even if the four paradigms operate at different levels of complexity: P3 and P4 evolve container theory thus operate at a higher complexity level while P2, and P1 mostly, still mirror a concept of system still considered as a omeostatic mechanism merely aimed at maintaining stability and equilibrium thus considering complexity as a problem. Getting on, this essay provides a deductive theorem of complexity and ease/complicatedness and simplicity of systemic evolution though the variety/density patterning.

Table 1. The Systemic Approach Paradigm Shifts (Pitasi in Pitasi-Mancini, 2012, 22)

\begin{tabular}{|c|c|c|}
\hline \multicolumn{3}{|c|}{$\begin{array}{c}\text { THE SYSTEMIC } \\
\text { APPROACH PARADIGM } \\
\text { SHIFTS } \\
\end{array}$} \\
\hline PARADIGM (P) & KEY AUTHORS & KEY CONCEPT \\
\hline P1) Whole/Part & $\begin{array}{l}\text { Ross Ashby } \\
\text { Norbert Wiener } \\
\text { Talcott Parsons } \\
\text { Ludwig von Bertalanffy } \\
\text { Anthony Stafford Beer } \\
\text { Ervin Laszlo }\end{array}$ & $\begin{array}{lr}\text { Culture, } & \text { control, } \\
\text { personality, } & \text { integration, } \\
\text { homeostasis, } & \text { stability, } \\
\text { wholeness, } & \text { structures, } \\
\text { parts. } & \end{array}$ \\
\hline P2) System/Environment & $\begin{array}{l}\text { Heinz von Forester } \\
\text { Niklas Luhmann }\end{array}$ & $\begin{array}{l}\text { Functional differentiation } \\
\text { system, communication, } \\
\text { order from noise }\end{array}$ \\
\hline P3) Autopoiesis & $\begin{array}{l}\text { Humberto Maturana } \\
\text { Francisco Varela } \\
\text { Niklas Luhmann }\end{array}$ & $\begin{array}{l}\text { Self production of inner } \\
\text { components, rhizome, } \\
\text { complexity, functional } \\
\text { equivalent fluctuation, } \\
\text { horizon. }\end{array}$ \\
\hline
\end{tabular}


P4) Enormous Constellation System
Richard Normann

Daniel Dennet (2004)

Niklas Luhmann
Flucting constellation, autopoietic reconfiguration, memetic complexity, catalog, global platform, enormity.

Let's start by conceptualizing the theorem definition:

"A theorem is a mathematical statement established by means of a proof" ( ClaphamNicholson, 2009: 781)

"a theorem is a statement which has been proved such as the Pythagorean theorem"

(Downing. 2009: 350)

By comparing these two conceptions and applying them to sociological thinking we can consider that a theorem is:

a) a statement

b) in this paper I do not mean to shape a mathematical one but a sociological one inspired by a mathematical epistemology

c) the matter it is a sociological theorem and not a mathematical one does not eliminate the fact it must be proved

e) nevertheless the kind of proof is different even if not completely.

The theorem consists on showing up that the more complex a system is the easier its trajectories and trends the simpler a system is the more implosive it becomes due to its complicatedness. Variety and density are the two key pattern variables which shape the complexity level of the operational closure of the system.

$\mathrm{P} 1$ and $\mathrm{P} 2$ represent simple and complicate systems founded on "culture" meant as tradition à là Parsons and discourses à là Foucault. Complex and easy systems are basically conceptualized by P3 and P4 in which culture is no longer considered as it was in P1 or P2, it rather evolves into contingency as clearly described by Luhmann (1988) in his essay "Warum AGIL?" and then it implies that culture can be meant as the indefinite, enormous (Dennet, 2004), unpredictable (Barber, 2009:250) variety of the possible memetic ricombinations generated by neocortex symbolic production which turns in self reproducing, limitless communication flows transcending any single agent-both individual and collective. That is why Beck's cosmopolitan vision is an exemplary case of the paradigm shift from P2 (the softest culture centered paradigm ) to P3 (the softest complexity based paradigm).

\subsection{The Case : Sorokin's Lost Lesson}

Sorokin's life and sociology were both inspired by great mobility. Just like many world class 
scholars such as, for example, Ernst von Glasersfeld and Elias Canetti, his life was a non-stop self construction/deconstruction/reconstruction and a paradigm for social mobility. In "one of his lives" he was Parsons' Department head at Harvard. When "Social and Cultural Dynamics a Study of Change in Mayor Systems of Art, Truth Ethics, Law and Social Relationships" appeared in 1957 , Parsons' The Social System was already six years old. Nevertheless in Sorokin's over 700 page work there is no question about Parsons. Considering the four, actually five as I am going to describe, key sociological dimensions of sociology and social change in mayor systems it is easy to understand why Sorokin ignored by purpose Parsons's work. Sorokin considers time, space, quantity and quality the four dimensions which co-evolve through a fifth one: fluctuations. Fluctuations describe trends, trajectories and shifting involvements among three very general kinds of system: idealistic, ideational and sensate. These are the three key patterns of relentless recombination of variants (in his semantics "mixed systems of culture", Sorokin, 1957: 20) to reconfigurate the five dimension patters. Sorokin had already focused on a variety of systems and on modelling dimensions which implied two reconfigurational features such as time and space (any book about globalization is nothing but an essay about the convergence of time and space) and two further dimensions (quantity and duality) which were the patterns to redesign the nonlinear links between variety and density. Luhmann asked: "Warum AGIL?" while Sorokin implicitly asked "why wasting time and energy discussing such a rigid and implosive idea of system which was already obsolete at the Ancient Romans Time?". Luhmann's vision implied social systems, contingency, variety ecc, thus a complexity level which AGIL was totally unable to grab.

Sorokin's systemic approach was open to variety, density, contingency. By Luhmann's demonstration of the contingency of AGIL and specifically of L (the cultural traditions reproduction according to Parsons') Luhmann, opens up to memetic complexity recombining. Nevertheless Sorokin's concept of culture (which anticipates Luhmann forseveral decades) is more rigid than Luhmann's but much more open and flexible than Parsons's tradition-based one. As a matter of fact, Sorokin states that "in the broadest sense it may mean the sum total of everything which is created or modified by the conscious or unconscious activity of two or more individuals interacting with one another or conditioning one another's behaviour" (Sorokin , 1957: 2). It was 1957 and Sorokin could not imagine that the 1980s on steps of systemic theory would have clearly argued that human interactions merely produce noise and only transcendental systemic coding of communication might produce sense. Nevertheless, Sorokin's concept of culture was already much more open to improbable and unusual than Parson's cultural tradition idea. What if Sorokin(1889-1968) and Luhmann (1927-1998) had met and Parsons would have kept on serving as a biologist never turning into a sociologist? One further key point of Sorokin's systemic approach which has been apparently forgotten by current sociologists is that data based research must operate at a level adequate to its conceptual and theoretical range. That is why, for example, that great and global changes cannot be observed and understood by merely collecting local, small research outputs. The social construction of research design inspired by Sorokin's lesson avoids:

a) Parsons' limit to think his specific point of view were the system

b) Merton's political escape into the middle range theory which is self defeating a sit implies 
that a collection of middle range theories might provide a general systematization

c)Luhmann's limit to ignore data and, for completely different reasons, Elias' same decision (Elias, 1969) in his book which crosses centuries and centuries of social change . Sorokin was aware that data are theoretical construction just like other theories. There is no reason to ignore data and, at the same time, there is no reason to consider data as something "real and concrete" which can verify /falsify theoretical abstractions as shown below, data tables for Sorokin are not other from theory, they are gears of the general convergence and consistency of the systemic construction:

\begin{tabular}{|c|c|c|c|c|c|c|c|}
\hline \multirow{2}{*}{$\begin{array}{l}\text { LOGICAL } \\
\text { SATELLITES }\end{array}$} & \multicolumn{7}{|c|}{ TYPES OF CULTURE MENTALITY } \\
\hline & $\begin{array}{c}\text { Ascetic } \\
\text { Ideational }\end{array}$ & $\begin{array}{l}\text { Active } \\
\text { Sensate }\end{array}$ & $\begin{array}{c}\text { Active } \\
\text { Ideational }\end{array}$ & Idealistic & $\begin{array}{l}\text { Passive } \\
\text { Sensale }\end{array}$ & $\begin{array}{l}\text { Cynical } \\
\text { Sensate }\end{array}$ & $\begin{array}{l}\text { Pseudo- } \\
\text { Ideational }\end{array}$ \\
\hline $\begin{array}{l}\text { 11. Moral val- } \\
\text { ues and systems }\end{array}$ & $\begin{array}{l}\text { absolute, } \\
\text { transcen- } \\
\text { dental, } \\
\text { categoric, } \\
\text { imperative, } \\
\text { everlasting, } \\
\text { and un- } \\
\text { changeable }\end{array}$ & $\begin{array}{l}\text { relativistic } \\
\text { and sen- } \\
\text { sate: hedo- } \\
\text { nistic, } \\
\text { eudaemonis- } \\
\text { tic, utilita- } \\
\text { rian; } \\
\text { seeking } \\
\text { maximum } \\
\text { sensate } \\
\text { happiness } \\
\text { for largest } \\
\text { number of } \\
\text { human } \\
\text { beings; } \\
\text { "morals of } \\
\text { rightly un- } \\
\text { derstood } \\
\text { egotism" }\end{array}$ & $\begin{array}{l}\text { both, with } \\
\text { emphasis } \\
\text { on the } \\
\text { absolute } \\
\text { and the } \\
\text { external }\end{array}$ & $\begin{array}{l}\text { both, } \\
\text { equally } \\
\text { emphasized }\end{array}$ & $\begin{array}{l}\text { no real } \\
\text { moral } \\
\text { values, } \\
\text { except } \\
\text { sensual, } \\
\text { "Wine, } \\
\text { women, } \\
\text { and song"; } \\
\text { amoralism; } \\
\text { nihilism }\end{array}$ & $\begin{array}{l}\text { no real } \\
\text { moral } \\
\text { values, } \\
\text { except } \\
\text { sensate } \\
\text { masked by } \\
\text { spiritual; } \\
\text { cynicism, } \\
\text { nihilism }\end{array}$ & $\begin{array}{l}\text { no differen- } \\
\text { tiated moral } \\
\text { system, ex- } \\
\text { cept apa- } \\
\text { thetic and } \\
\text { dull submis- } \\
\text { sion to fate, } \\
\text { and sensual } \\
\text { disapproval } \\
\text { of hard } \\
\text { blows and } \\
\text { approval of } \\
\text { easier times } \\
\text { followed by } \\
\text { vague ideas } \\
\text { about the } \\
\text { other } \\
\text { world's } \\
\text { justice }\end{array}$ \\
\hline $\begin{array}{l}\text { 12. Aesthetic } \\
\text { values }\end{array}$ & $\begin{array}{l}\text { "idea-, } \\
\text { tional" } \\
\text { subservient } \\
\text { to the main } \\
\text { inner } \\
\text { values, re- } \\
\text { ligpous, } \\
\text { nonsensate }\end{array}$ & $\begin{array}{l}\text { sensate, } \\
\text { secular, } \\
\text { created to } \\
\text { increase } \\
\text { joys and } \\
\text { beauties of } \\
\text { a rich sen- } \\
\text { sate life }\end{array}$ & $\begin{array}{l}\text { both, with } \\
\text { emphasis } \\
\text { on the non- } \\
\text { sensate }\end{array}$ & $\begin{array}{l}\text { both, } \\
\text { equally } \\
\text { emphasized }\end{array}$ & $\begin{array}{l}\text { narrow } \\
\text { sensual; } \\
\text { refinedly } \\
\text { pathologic }\end{array}$ & $\begin{array}{l}\text { sensate, } \\
\text { masked } \\
\text { with spirit- } \\
\text { ual }\end{array}$ & $\begin{array}{l}\text { undifferen- } \\
\text { tiated and } \\
\text { vague }\end{array}$ \\
\hline $\begin{array}{l}\text { 13. Social and } \\
\text { practical values }\end{array}$ & $\begin{array}{l}\text { those which } \\
\text { are lasting } \\
\text { and lead to } \\
\text { the ulti- } \\
\text { mate real- } \\
\text { ity only } \\
\text { such per- } \\
\text { sons are } \\
\text { leaders, } \\
\text { only such } \\
\text { things and } \\
\text { events are } \\
\text { positive, all } \\
\text { others are } \\
\text { valueless, } \\
\text { or of nega- } \\
\text { tive value, } \\
\text { particularly } \\
\text { wealth, } \\
\text { earthly } \\
\text { comfort, } \\
\text { etc.; prin- } \\
\text { ciple of } \\
\text { sacrifice }\end{array}$ & $\begin{array}{l}\text { everything } \\
\text { that gives } \\
\text { joy of life } \\
\text { to self and } \\
\text { partly to } \\
\text { others: } \\
\text { particularly } \\
\text { wealth, } \\
\text { comfort, } \\
\text { etc.; pres- } \\
\text { tige is } \\
\text { based on } \\
\text { the above; } \\
\text { wealth, } \\
\text { money, } \\
\text { physical } \\
\text { might be- } \\
\text { come } \\
\text { "rights" } \\
\text { and basis } \\
\text { of all } \\
\text { values; } \\
\text { principle of } \\
\text { sound ego- } \\
\text { tism }\end{array}$ & $\begin{array}{l}\text { both, with } \\
\text { emphasis } \\
\text { on spiritual }\end{array}$ & $\begin{array}{l}\text { both, } \\
\text { equally. } \\
\text { empha- } \\
\text { sized; live } \\
\text { and let live }\end{array}$ & $\begin{array}{l}\text { narrow and } \\
\text { extremely } \\
\text { sensual; } \\
\text { "après moi } \\
\text { le déluge" }\end{array}$ & $\begin{array}{l}\text { narrow and } \\
\text { extremely } \\
\text { sensual } \\
\text { with a } \\
\text { mask of } \\
\text { spiritual } \\
\text { values; } \\
\text { Tartufeism }\end{array}$ & $\begin{array}{l}\text { no choice } \\
\text { given; un- } \\
\text { differenti- } \\
\text { ated; as } \\
\text { God or boss } \\
\text { decides } \\
\text { - }\end{array}$ \\
\hline
\end{tabular}

Figure 1. As witnessed in his 1957 book

Sorokin was able to let very microtrends co-evolve through the ages whit no need to state a rigid, stable equilibrium model as shown in Figure 1 and below in figures 2 and 3 


\begin{tabular}{|c|c|c|c|c|c|c|c|}
\hline \multirow{2}{*}{$\begin{array}{l}\text { MAIN } \\
\text { ELEMENTS }\end{array}$} & \multicolumn{7}{|c|}{ TYPES OF CULTURE MENTALITY } \\
\hline & $\begin{array}{l}\text { Ascetic } \\
\text { Ideational }\end{array}$ & $\begin{array}{l}\text { Active } \\
\text { Sensale }\end{array}$ & $\begin{array}{c}\text { Active } \\
\text { Ideational }\end{array}$ & Idealistic & $\begin{array}{l}\text { Passive } \\
\text { Sensate }\end{array}$ & $\begin{array}{l}\text { Cynical } \\
\text { Sensale }\end{array}$ & $\begin{array}{l}\text { Pseudo- } \\
\text { Ideational }\end{array}$ \\
\hline I. Reality & $\begin{array}{l}\text { ultimate } \\
\text { reality, } \\
\text { eternal, } \\
\text { nonsen- } \\
\text { sate, tran- } \\
\text { scendental }\end{array}$ & $\begin{array}{l}\text { sensate, } \\
\text { empirical, } \\
\text { material }\end{array}$ & $\begin{array}{l}\text { both, with } \\
\text { emphasis } \\
\text { on the } \\
\text { eternal and } \\
\text { nonsensate }\end{array}$ & $\begin{array}{l}\text { both ap- } \\
\text { proximately } \\
\text { equally } \\
\text { represented }\end{array}$ & $\begin{array}{l}\text { sensate, } \\
\text { narrow, and } \\
\text { shallow }\end{array}$ & $\begin{array}{l}\text { sensate, but } \\
\text { with spirit- } \\
\text { ual mask }\end{array}$ & $\begin{array}{l}\text { painfully } \\
\text { sensate; } \\
\text { spiritual, } \\
\text { but undif- } \\
\text { ferentiated; } \\
\text { felt and } \\
\text { sensed but } \\
\text { not thought } \\
\text { through } \\
\text { (uninte- } \\
\text { grated) }\end{array}$ \\
\hline $\begin{array}{l}\text { 2. Main nceds } \\
\text { and ends }\end{array}$ & spiritual & $\begin{array}{l}\text { manifold } \\
\text { and richly } \\
\text { sensate }\end{array}$ & $\begin{array}{l}\text { both, with } \\
\text { predomi- } \\
\text { nance of } \\
\text { spiritual }\end{array}$ & $\begin{array}{l}\text { both ap- } \\
\text { proximately } \\
\text { equally } \\
\text { represented }\end{array}$ & $\begin{array}{l}\text { narrow } \\
\text { sensate }\end{array}$ & $\begin{array}{l}\text { sensate, } \\
\text { with a } \\
\text { spiritual } \\
\text { mask }\end{array}$ & $\begin{array}{l}\text { mainly sen- } \\
\text { sate, with } \\
\text { elements of } \\
\text { spiritual } \\
\text { not differ- } \\
\text { entiated }\end{array}$ \\
\hline $\begin{array}{l}\text { 3. Extent of sal- } \\
\text { isfaction }\end{array}$ & maximum & maximum & $\begin{array}{l}\text { great, but } \\
\text { moderated }\end{array}$ & $\begin{array}{l}\text { great, but } \\
\text { balanced }\end{array}$ & $\begin{array}{l}\text { maximum } \\
\text { for narrow } \\
\text { sensate } \\
\text { needs }\end{array}$ & $\begin{array}{l}\text { according } \\
\text { to circum- } \\
\text { stances }\end{array}$ & $\begin{array}{l}\text { very } \\
\text { limited }\end{array}$ \\
\hline $\begin{array}{l}\text { 4. Method of } \\
\text { satisfaction }\end{array}$ & $\begin{array}{l}\text { mainly self- } \\
\text { modifica- } \\
\text { tion }\end{array}$ & $\begin{array}{l}\text { mainly } \\
\text { modifica- } \\
\text { tion of ex- } \\
\text { ternal } \\
\text { milieu }\end{array}$ & $\begin{array}{l}\text { both ways, } \\
\text { with the } \\
\text { prevalence } \\
\text { of self- } \\
\text { modifica- } \\
\text { tion }\end{array}$ & both ways & $\begin{array}{l}\text { utilization } \\
\text { of external } \\
\text { miliey }\end{array}$ & $\begin{array}{l}\text { milieu's } \\
\text { utilization } \\
\text { through } \\
\text { superficial } \\
\text { and purely } \\
\text { external } \\
\text { change of } \\
\text { the psycho- } \\
\text { social traits } \\
\text { of the per- } \\
\text { son, with- } \\
\text { out change } \\
\text { of itself }\end{array}$ & $\begin{array}{l}\text { mere en- } \\
\text { forced en- } \\
\text { durance of } \\
\text { the milieu }\end{array}$ \\
\hline \multicolumn{8}{|l|}{$\begin{array}{c}\text { LOGICAL } \\
\text { SATELLITES }\end{array}$} \\
\hline $\begin{array}{l}\text { 5. Weltanschau- } \\
\text { ung }\end{array}$ & $\begin{array}{l}\text { Being } \\
\text { (Sein): } \\
\text { lasting } \\
\text { value; in- } \\
\text { difference } \\
\text { to transient } \\
\text { values; } \\
\text { imperturb- } \\
\text { ability; } \\
\text { statism }\end{array}$ & $\begin{array}{l}\text { Becoming } \\
\text { (Werden): } \\
\text { transient } \\
\text { values; } \\
\text { full- } \\
\text { blooded } \\
\text { sense of } \\
\text { life, joy, } \\
\text { and grief; } \\
\text { dynamism } \\
\text { and endless } \\
\text { readjust- } \\
\text { ment } \\
\text { (progress, } \\
\text { cvolution) }\end{array}$ & $\begin{array}{l}\text { both, with } \\
\text { emphasis } \\
\text { on Being }\end{array}$ & $\begin{array}{l}\text { both } \\
\text { equally } \\
\text { represented }\end{array}$ & $\begin{array}{l}\text { narrow and } \\
\text { extreme } \\
\text { Becoming, } \\
\text { ("Carpe } \\
\text { diem") }\end{array}$ & $\begin{array}{l}\text { narrow } \\
\text { Becoming, } \\
\text { with a } \\
\text { mask of } \\
\text { Being }\end{array}$ & $\begin{array}{l}\text { undifferen- } \\
\text { tiated and } \\
\text { not thought } \\
\text { through, } \\
\text { vague and } \\
\text { fragmen- } \\
\text { tary ideas } \\
\text { (lack of in- } \\
\text { tegration) }\end{array}$ \\
\hline $\begin{array}{l}\text { 6. Power and } \\
\text { object of control }\end{array}$ & $\begin{array}{l}\text { self-control, } \\
\text { repression } \\
\text { of the sen- } \\
\text { sual man } \\
\text { and of } \\
\text { "self" }\end{array}$ & $\begin{array}{l}\text { control of } \\
\text { the sensate } \\
\text { reality }\end{array}$ & $\begin{array}{l}\text { both, with } \\
\text { emphasis } \\
\text { on self- } \\
\text { control }\end{array}$ & $\begin{array}{l}\text { both } \\
\text { equally } \\
\text { represented }\end{array}$ & $\begin{array}{l}\text { no real } \\
\text { control of } \\
\text { either self } \\
\text { or milieu }\end{array}$ & $\begin{array}{l}\text { control of } \\
\text { assuming } \\
\text { and put- } \\
\text { ting off } \\
\text { masks }\end{array}$ & $\begin{array}{l}\text { no control: } \\
\text { mere endur- } \\
\text { ance of the } \\
\text { effects of } \\
\text { other forces } \\
\text { acted on by } \\
\text { external } \\
\text { power }\end{array}$ \\
\hline
\end{tabular}

Figure 2. 


\section{$\triangle \|_{\text {Institute }}^{\text {Macrothink }}$}

Journal of Sociological Research

ISSN 1948-5468

2014, Vol. 5, No.1

\begin{tabular}{|c|c|c|c|c|c|c|c|}
\hline \multirow{2}{*}{$\begin{array}{l}\text { LOGICAL } \\
\text { SATELLITES }\end{array}$} & \multicolumn{7}{|c|}{ TYPES OF CULTURE MENTALITY } \\
\hline & $\begin{array}{c}\text { Ascetic } \\
\text { Ideational }\end{array}$ & $\begin{array}{l}\text { Active } \\
\text { Sensate }\end{array}$ & $\begin{array}{c}\text { Active } \\
\text { Idealional }\end{array}$ & Idealistic & $\begin{array}{l}\text { Passive } \\
\text { Sensate }\end{array}$ & $\begin{array}{l}\text { Cynical } \\
\text { Sensate }\end{array}$ & $\begin{array}{l}\text { Pseuda- } \\
\text { Ideational }\end{array}$ \\
\hline 7. Activity & introvert & extrovert & $\begin{array}{l}\text { both, with } \\
\text { emphasis } \\
\text { on intro- } \\
\text { vert }\end{array}$ & $\begin{array}{l}\text { both } \\
\text { equally } \\
\text { represented }\end{array}$ & $\begin{array}{l}\text { parasitism } \\
\text { of intro- } \\
\text { vert-extro- } \\
\text { vert type }\end{array}$ & $\begin{array}{l}\text { specific } \\
\text { introvert- } \\
\text { extrovert }\end{array}$ & $\begin{array}{l}\text { enforced } \\
\text { extrovert- } \\
\text { introvert; } \\
\text { fatalistic }\end{array}$ \\
\hline 8. Self & $\begin{array}{l}\text { highly inte- } \\
\text { grated, } \\
\text { spiritual, } \\
\text { dissolved in } \\
\text { the ulti- } \\
\text { mate real- } \\
\text { ity, aware } \\
\text { of the sen- } \\
\text { sual world } \\
\text { as illusion } \\
\text { or content } \\
\text { of self; } \\
\text { antimate- } \\
\text { rialistic }\end{array}$ & $\begin{array}{l}\text { highly inte- } \\
\text { grated, } \\
\text { sensate, } \\
\text { dissolved in } \\
\text { immediate } \\
\text { physical } \\
\text { reality; } \\
\text { material- } \\
\text { izes self } \\
\text { and all the } \\
\text { spiritual } \\
\text { phenom- } \\
\text { ena; mate- } \\
\text { rialistic, } \\
\text { caring for } \\
\text { integrity of } \\
\text { body and } \\
\text { its sensual } \\
\text { interest. } \\
\text { Sensual lib- } \\
\text { erty, sen- } \\
\text { sual egotism }\end{array}$ & $\begin{array}{l}\text { both, with } \\
\text { emphasis } \\
\text { on spirit- } \\
\text { ual, etc. }\end{array}$ & $\begin{array}{l}\text { both } \\
\text { equally } \\
\text { represented }\end{array}$ & $\begin{array}{l}\text { no real in- } \\
\text { tegration } \\
\text { of self; } \\
\text { mere flux of } \\
\text { uninte- } \\
\text { grated } \\
\text { physical } \\
\text { sensations; } \\
\text { self almost } \\
\text { identical } \\
\text { with stom- } \\
\text { ach, sex } \\
\text { organs, etc. }\end{array}$ & $\begin{array}{l}\text { no real in- } \\
\text { tegration; } \\
\text { similar to } \\
\text { the passive } \\
\text { sensate, } \\
\text { but schem- } \\
\text { ing and } \\
\text { manipulat- } \\
\text { ing }\end{array}$ & $\begin{array}{l}\text { no inte- } \\
\text { grated self, } \\
\text { except as a } \\
\text { vague cen- } \\
\text { ter of sensa- } \\
\text { tions; with } \\
\text { some fanci- } \\
\text { ful, animis- } \\
\text { tic, or other, } \\
\text { ideas and } \\
\text { images; re- } \\
\text { mains on a } \\
\text { half-animal } \\
\text { level (unin- } \\
\text { tegrated) }\end{array}$ \\
\hline 9. Knowledge & $\begin{array}{l}\text { develops } \\
\text { insight into } \\
\text { and cogni- } \\
\text { tion of the } \\
\text { spiritual, } \\
\text { psychical, } \\
\text { immaterial } \\
\text { phenomena } \\
\text { and experi- } \\
\text { ences; con- } \\
\text { centrates } \\
\text { upon these } \\
\text { exclu- } \\
\text { sively; } \\
\text { leads to } \\
\text { arts of edu- } \\
\text { cation and } \\
\text { modifica- } \\
\text { tion of } \\
\text { man's inner } \\
\text { life }\end{array}$ & $\begin{array}{l}\text { develops } \\
\text { science of } \\
\text { natural } \\
\text { phenomena } \\
\text { and techni- } \\
\text { cal inven- } \\
\text { tions; con- } \\
\text { centrates } \\
\text { on these; } \\
\text { leads to } \\
\text { arts of } \\
\text { technology, } \\
\text { medicine, } \\
\text { hygiene, } \\
\text { sanitation, } \\
\text { and modif- } \\
\text { cation of } \\
\text { man's } \\
\text { physical } \\
\text { actions }\end{array}$ & $\begin{array}{l}\text { both, but } \\
\text { more mod- } \\
\text { erately, } \\
\text { with em- } \\
\text { phasis on } \\
\text { the spirit- } \\
\text { ual }\end{array}$ & $\begin{array}{l}\text { both, } \\
\text { equally } \\
\text { represented }\end{array}$ & $\begin{array}{l}\text { develops } \\
\text { only the } \\
\text { "culinary" } \\
\text { and "bed- } \\
\text { room" } \\
\text { techniques } \\
\text { of sensual } \\
\text { enjoyment }\end{array}$ & $\begin{array}{l}\text { same as in } \\
\text { passive } \\
\text { sensate } \\
\text { plus the } \\
\text { technique } \\
\text { of decep- } \\
\text { tion and } \\
\text { hypocrisy }\end{array}$ & $\begin{array}{l}\text { does not } \\
\text { give any } \\
\text { real oppor- } \\
\text { tunity to } \\
\text { develop any } \\
\text { form of in- } \\
\text { tegrated } \\
\text { knowledge } \\
\text { and cogni- } \\
\text { tion except } \\
\text { some frag- } \\
\text { ments } \\
\text { acquired } \\
\text { through im- } \\
\text { posed "trial } \\
\text { and error" }\end{array}$ \\
\hline $\begin{array}{l}\text { 10. Truth, its } \\
\text { categories, criteria, } \\
\text { and methods (of ar- } \\
\text { riving at) }\end{array}$ & $\begin{array}{l}\text { based on } \\
\text { inner ex- } \\
\text { perience, } \\
\text { "mystic } \\
\text { way," con- } \\
\text { centrated } \\
\text { medita- } \\
\text { tion; in- } \\
\text { tuition } \\
\text { and "reve- } \\
\text { lation"; } \\
\text { prophecy }\end{array}$ & $\begin{array}{l}\text { based on } \\
\text { observation } \\
\text { of, meas- } \\
\text { urernent of, } \\
\text { experimen- } \\
\text { tation with, } \\
\text { the exterior } \\
\text { phenomena } \\
\text { through } \\
\text { exterior } \\
\text { organs of } \\
\text { senses, } \\
\text { inductive } \\
\text { logic }\end{array}$ & $\begin{array}{l}\text { both, with } \\
\text { the "inner } \\
\text { way" em- } \\
\text { phasized }\end{array}$ & $\begin{array}{l}\text { botl, } \\
\text { equally } \\
\text { emphasized } \\
\text { (Scholasti- } \\
\text { cism) }\end{array}$ & $\begin{array}{l}\text { nothing } \\
\text { coherent, } \\
\text { no truth } \\
\text { except sen- } \\
\text { sations }\end{array}$ & $\begin{array}{l}\text { nothing } \\
\text { coherent }\end{array}$ & $\begin{array}{l}\text { nothing dif- } \\
\text { ferentiated } \\
\text { and thought } \\
\text { through } \\
\text { clearly }\end{array}$ \\
\hline
\end{tabular}

Figure 3. 


\section{MlMacrothink}

\section{Final remarks and findings/conclusions}

The concept of complex system is one of the most powerful and challenging in current interdisciplinary epistemology and scientific debate in which sociology is profoundly involved, nevertheless it is often misunderstood in public debates due to the negative semantic shades coming from past ideas of science much more linear causality based and by common sense (and mass media) current semantics which confuses complex and complicate and considers complexity as a subject thing, an item and not as an epistemological and methodological criterion. Complex systems requires and imply:

a) a high level of conceptual abstraction

b) a chaotic mathematics of variety /density dynamic ad instable "equilibria"

c) a container conception of theory

d) a transcendental approach to systems

e) radical de-materializing paradigm shifts

f) a convergent approach to theory and data as mutually modelling constructions and further features all of them co-evolving through nonlinear trends.

\section{References}

Barber, N. (2009). The Myth of Culture. Newcastle: Cambridge Scholars Publishing.

Beck, U. (2006). The Cosmopolitan Vision. Cambridge: Polity Press.

Beck, U. (2005). Power in the Global Age. Cambridge: Polity Press.

Beck, U. (2000). What is Globalization? . Cambridge: Polity Press.

P. Berger, P., Luckmann, T. (1966). The Social Construction of Reality. London: Penguin.

Berger, P., Berger, B., Kellner, H. (1973). The Homeless Mind. London:Vintage Books.

Burawoy, M. (2014). Introduction: Sociology as a combat sport. Current Sociology. 62, nr 2, monograph 1, March 2014.

Clapham, C., Nicholson, J. (2009). Oxford Concise Dictionary of Mathematics. London: Oxford U Press.

Dennet, D. (2004). Evolves. London: Penguin.

Downing, D. (2009). Dictionary of Mathematics Terms. New York: Barrons.

Elias, N. (1969). The Civilizing Process. London: Blackwell.

Goudsblom , J. (1994). Fire and Civilization. London: Penguin.

Imada, T. (2008). Self Organization and Society. Tokyo: Springer.

Luhmann, N. (1990). Essays On Self reference. New York: Columbia University Press.

Luhmann, N. (1988). Why AGIL?; Warum AGIL?, Kolner Zeitschrift für Soziologie und Sozialpsychologie, 40 (1).

Pitasi, A. (2011). The Hyperhuman World. Saarbruecken: Lambert Academic Publishing.

Pitasi, A. (2012). Hypercitizenship and the Management of Genetic Diversity: Sociology of Law and the Key Systemic Bifurcation Between the Ring Singularity and the Neofeudal Age? World Futures Journal, 68, 314- 331.

Pitasi, A., Mancini, G. (2012). Systemic Shifts in Sociology. Saarbruecken: Lambert Academic Publishing. 
Robyn, R. (2005). The Changing Face of European Identity. London: Routledge.

Seabright, P. (2010). The company of strangers: a natural history of economic life. (2nd ed.).

Princeton, NJ: Princeton University Press.

Urry, J. (2003). Global Complexity. Cambridge: Polity Press. 